\title{
PENGARUH BAURAN PEMASARAN TERHADAP KEPUTUSAN KONSUMEN MENGGUNAKAN PRODUK EIGER DI UNIVERSITAS TADULAKO
}

\author{
Sultan Prayudha Putra \\ Enki P. Nainggolan \\ Program Studi Manajemen S1, Fakultas Ekonomi Universitas Tadulako \\ Emai : prayudhaputra66@gmail.com; enki.nainggolan@ yahoo.com;
}

\begin{abstract}
This research aims to determine the simultaneous and partial influence of the marketing mix consisting of products, prices, promotions, and places on consumer decisions using Eiger Products at Tadulako University. This research used primary data, obtained directly from questionnaries filled out by respondents. The Population in this research was students of Tadulako University. The sample in this research amounted to 60 respondents who were determined using the purposive sampling method. Data analysis method used multiple linear regression analysis method.

The results of this research show that the significance value is less than 0.05 which is equal to 0,000, so it can be concluded that simultaneous marketing mix has a significant effect on puchasing decisions of Eiger products at Tadulako University. Value of $R^{2}=0.871$ or $87.1 \%$. This means that $87.1 \%$ of eiger product purchase decisions at Tadulako University are influenced by the marketing mix variable. From the partial test result $(t)$ obtained significance value of the product variable is 0.012, the significance value of the price variable is 0,001, the significance value of the promotion variable is 0,001, while the significance value of the place variable is 0,000. Because the significance value of all marketing mix variable is less than 0,05, it can be concluded that the marketing mix variable consisting of product, price, promotion and place partially has a significant effect on purchasing decisions of Eiger products at Tadulako University.
\end{abstract}

Keywords: Marketing Mix (Product, Price, Promotion, Place), Consumer Purchasing Decision

\begin{abstract}
Abstrak
Penelitian ini bertujuan untuk mengetahui pengaruh simultan maupun parsial bauran pemasaran yang terdiri dari produk, harga, promosi dan tempat terhadap keputusan konsumen menggunakan produk Eiger di Universitas Tadulako. Penelitian ini menggunakan data primer, yang diperoleh secara langsung dari kuesioner yang diisi oleh responden. Populasi dalam penelitian ini adalah mahasiswa Universitas Tadulako. Sampel dalam penelitian ini berjumlah 60 responden yang ditentukan menggunakan metode purposive sampling. Metode analisis data yang digunakan adalah metode analisis regresi linear berganda.

Hasil penelitian menunjukkan bahwa nilai signifikansi lebih kecil dari 0,05 yakni sebesar 0,000, sehingga dapat disimpulkan bahwa secara simultan bauran pemasaran berpengaruh signifikan terhadap keputusan pembelian produk Eiger di Universias Tadulako. Nilai $\mathrm{R}^{2}=0,871$ atau $87,1 \%$. Artinya bahwa 87,1\% keputusan pembelian produk Eiger di Universitas Tadulako dipengaruhi oleh variabel bauran pemasaran. Dari hasil uji parsial (t) diperoleh nilai signifikansi variabel produk sebesar 0,012, nilai signifikansi variabel harga sebesar 0,001 , nilai signifikansi variabel promosi sebesar 0,001 , sedangkan nilai signifikansi variabel tempat sebesar 0,000. Karena nilai signifikansi semua variabel bauran pemasaran lebih kecil dari 0,05, maka dapat disimpulkan bahwa secara parsial variabel bauran
\end{abstract}


pemasaran yang terdiri dari produk, harga, promosi dan tempat secara parsial berpengaruh sigifikan terhadap keputusan pembelian produk Eiger di Universias Tadulako.

Kata Kunci : Bauran Pemasaran (Produk, Harga, Promosi, Tempat), Keputusan Pembelian Konsumen

\section{PENDAHULUAN}

Kegiatan berpetualang kini menjadi gaya hidup baru dikalangan masyarakat terutama bagi mahasiswa khususnya mahasiswa di Universitas Tadulako. Mereka gemar melakukan kegiatan seperti outbond, panjat tebing, menyusuri goa, mendaki gunung dan kegiatan-kegiatan petualangan lainnya yang kini marak bermunculan dimana-mana. Kegiatan-kegiatan seperti ini tentunya harus didukung dengan peralatan-peralatan berpetualang yang lengkap dan berkualitas yang diharapkan mampu menunjang keberhasilan dan kenyamanan dalam melakukan setiap kegiatan yang ada. Hal-hal inilah yang akhirnya memicu banyaknya peminat produk adventure di Universitas Tadulako, yang terutama terpaut pada produk-produk adventure milik Eiger. Eiger adalah produk peralatan outdoor dan tas yang banyak digemari pencinta alam maupun anak muda karena kualitas dan ketahanannya. Selain itu Eiger juga merupakan produk lokal, dimana perusahaannya didirikan oleh seorang pengusaha tas yang bernama Ronny Lukito di Bandung pada tahun 1993, dengan nama perusahaan PT Eigerindo Multi Produk Industri atau PT Eiger. Perusahaan ini mempunyai tiga merek utama yakni Eiger, Bodypack dan Norwand. Olehnya itu dalam melakukan penjualan tentunya Eiger membutuhkan kegiatan pemasaran yang terdiri dari empat yaitu produk (product), harga (price), tempat (place) dan promosi (promotion) yang disebut dengan bauran pemasaran (Marketing Mix).

Charles lamb, W. dkk (2001 : 55) berpendapat bahwa bauran pemasaran merupakan komponen yang terdiri dari produk, promosi, tempat dan harga yang saling berpengaruh satu sama lain yang disusun untuk memperoleh hasil pertukaran yang saling meguntungkan. Produk merupakan barang atau jasa yang dipasarkan untuk memenuhi keinginan konsumen (Kotler, 2005 : 69). Produk yang ditawarkan oleh Eiger adalah peralatan petualangan dan peralatan alam bebas yang terdiri dari tas, pakaian, aksesoris, topi, sepatu, sandal dan peralatan petualangan lainnya (Febrian, 2013). Harga adalah alat pembayaran yang ditukarkan untuk mendapatkan produk atau jasa yang diinginkan (Kotler, 2005 : 340). Dalam kegiatan penjualannya Eiger menawarkan harga produknya mulai dari kisaran kurang dari Rp. 200.000 hingga produk dengan harga di atas Rp. 1.000.000 (Febrian, 2013). Saluran distribusi adalah lembaga yang bekerjasama dalam upaya memasarkan barang maupun jasa agar dapat dikonsumsi (Kotler, 2005 : 181). Dalam pendistribusian produknya Eiger melakukan cara offline dan online. Dimana secara offline pihak Eiger turun langsung dalam event-event yang mereka adakan untuk membangun hubungan dengan konsumennya. Sedangkan secara online pihak Eiger aktif memperkenalkan produknya melaui sosial media (Infobgd.com, 2018). Sedangkan Promosi penjualan adalah kompensasi yang dilakukan perusahaan guna memicu keinginan konsumen untuk membeli barang atau jasa yang diperdagangkan (Kotler, 2005 : 298). Adapun kegiatan promosi Eiger yaitu mengenalkan produknya melalui media cetak dan media masa, serta mempromosikan produknya melaui internet dan web resminya. Selain itu Eiger juga mendukung kegiatan-kegiatan yang bertema petualangan dan memberi harga khusus bagi anggota dan komunitas-komunitas Eiger (Febrian, 2013).

\section{KAJIAN LITERATURE}

Menurut Tjiptono dan Adriana (2008) pemasaran adalah aktivitas perorangan atau kelompok dalam memudahkan proses jual beli yang saling menguntungkan melalui pengembangan, distribusi, promosi dan penetapan harga barang, jasa dan gagasan. Pemasaran menjadi sarana untuk memenuhi kebutuhan dan keinginan manusia. Adapun konsep pemasaran terdiri dari produk, harga, tempat dan promosi. Dalam Kotler dan Keller (2009 : 5) dikemukakan bahwa manajemen pemasaran merupakan suatu kreasi dan keahlian dalam menentukan pasar sasaran serta menggapai, menentukan dan meningkatkan 
konsumen dengan membuat, mendorong serta menginformasikan nilai konsumen yang unggul. Charles lamb, W. dkk (2001 : 55) menyatakan bahwa bauran pemasaran merupakan susunan yang terdiri dari produk, promosi, tempat dan harga yang saling mempengaruhi dengan tujuan untuk memperoleh hasil pertukaran yang saling meguntungkan.

Kotler dan Keller (2009 : 4) berpendapat bahwa setiap apa saja yang bisa dijual oleh perusahaan dalam pasar untuk memenuhi suatu keinginan dan kebutuhan konsumen baik dalam bentuk barang, fisik, jasa, pengalaman, acara, orang, tempat, properti, organisasi, informasi maupun ide disebut produk. Kotler dan Amstrong (2008 : 345) mengemukakan bahwa harga merupakan jumlah nilai, yang dipakai untuk membayar barang atau jasa yang sudah di gunakan atau sudah diambil manfaatnya oleh konsumen. Menurut Kotler (2005 : 181) institusi yang bekerjasama dalam upaya menawarkan barang maupun jasa agar dapat dikonsumsi disebut saluran distribusi. Kotler dan Amstrong (2008: 63) berpendapat bahwa promosi merupakan kegiatan menginformasikan keunggulan suatu produk untuk memicu minat konsumen agar tertarik untuk membeli.

Kotler dan Keller (2009 : 166) berpendapat bahwa perilaku konsumen merupakan ilmu yang mempelajari tentang bagaimana seseorang, golongan, serta lembaga menentukan, mengkonsumsi, menggunakan dan bagaimana barang, jasa, pikiran atau pengalaman guna memuaskan kebutuhan serta selera konsumen. Hal yang perlu diketahui dalam upaya memahami perilaku konsumen yaitu model respon rangsangan. Rangsangan pemasaran dan lingkungan memasuki kesadaran konsumen, dan sekolompok proses psikologis digabungkan dengan kriteria konsumen tertentu menghasilkan proses pengambilan keputusan dan keputusan akhir pembelian (Kotler dan Keller, 2009 : 176). Kemudian Kotler dan Keller (2012) berpendapat bahwa keputusan pembelian merupakan suatu langkah nyata yang diambil oleh konsumen untuk membeli suatu produk.

\section{METODE PENELITIAN}

Menurut Ravers (dalam Umar, 2003 : 87) metode deskriptif adalah teknik yang digunakan untuk mendeskripsikan keadaan suatu subjek dan objek pada saat melakukan penelitian serta untuk menyelidiki apa saja penyebab terjadinya suatu masalah dalam penelitian tersebut. Sedangkan Kausal merupakan suatu penelitian dengan tujuan untuk mendapatkan informasi mengenai pengaruh antara satu variabel dengan variabel lainnya. Penelitian ini dilakukan terhadap pengguna produk Eiger di Universitas Tadulako. Dengan objek penelitian yaitu pengaruh bauran pemasaran terhadap keputusan konsumen menggunakan produk Eiger di Universitas tadulako. Adapun jumlah sampel yang akan diambil dalam penelitian ini adalah 60 orang. Roscoe (1975) yang dikutip Uma Sekaran (2006) yang menyatakan bahwa suatu ukuran sampel lebih dari 30 dan kurang dari 500 adalah tepat.

Uji validitas dimaksudkan untuk memastikan valid tidaknya sebuah koesioner. Jika item-item dalam koesioner dapat menghasilkan informasi yang dibutuhkan dalam penelitian maka koesioner dikatakan valid (Azwar, 2003 : 54). Agar dapat mengetahui valid atau tidaknya suatu instrumen, maka digunakan uji validitas kesahiban butir, menggunakan teknik Product Moment Correlation. Kriteria pengujiannya adalah jika korelasi antar item dengan skor total seluruh item suatu variabel $>0,30$ maka instrumen tersebut dinyatakan valid. Namun sebaliknya jika korelasi antar item dengan skor total seluruh item suatu variabel $<0,30$ maka instrumen tersebut dinyatakan tidak valid.

Uji reliabilitas berfungsi untuk mengukur suatu koesioner yang merupakan indikator dari variabel atau konstruk. Jika jawaban responden konsisten dengan pertanyaan dalam koesioner apabila dilakukan pengukuran dua kali atau lebih maka sebuah koesioner dianggap reliable. Menurut Sujarweni (2014 : 193) suatu koesioner dikatakan reliable jika nilai Cronbach's Alpha >0,60, sebaliknya jika nilai Cronbach's Alpha $<0,60$ maka koesioner dianggap tidak reliabel. 
Model pengujian klasik bertujuan untuk mengatasi masalah-masalah yang terjadi dalam pengujian model regresi. Pengujian ini terbagi menjadi tiga yaitu:

1. Uji Normalitas

Uji Normalisasi bertujuan menguji apakah data yang digunakan dalam penelitian berdistribusi normal atau tidak, karena data yang baik adalah data yang mempunyai distribusi normal. Adapun cara yang digunakan untuk menguji normalitas yaitu melalui uji Kolmogorov Smirnov. Uji ini dilakukan untuk mengetahui nilai signifikannya, dimana jika nilai signifikansi lebih besar dari 0,05 maka data yang diuji dianggap berdistribusi normal (Ghozali, $2006: 110$ ).

2. Uji Multikolinieritas

Uji multikolinieritas berfungsi untuk menguji apakah dalam suatu model regresi ditemukan adanya korelasi antara variabel independen atau tidak. Dalam model regresi yang baik seharusnya tidak terjadi korelasi diantara variabel independen. Adapun dasar pengambilan keputusan dalam uji multikolinieritas ini yaitu dengan tolerance dan VIF. Apabila nilai tolerance lebih besar dari 0,10 maka tidak teradi multikolinieritas dalam model regresi, dan apabila nilai VIF $<10,00$ berarti tidak terjadi multikolinieritas dalam model regresi.

3. Uji Heteroskedastisitas

Uji ini dilakukan untuk menilai apakah terdapat penyimpangan variasi dari nilai residual pengamatan dalam suatu model regresi. Dalam hal ini heterokedastisitas terjadi apabila variasi nilai residual semua pengamatan tidak sama antara satu dengan yang lainnya. Sedangkan apabila nilai residual semua pengamatan tetap sama maka dinamakan sebagai homoskedastisitas. Jika heteroskedastisitas tidak terjadi maka model regresi tersebut dianggap valid. Adapun cara yang digunakan untuk menguji heterokedastisitas yaitu dengan menggunakan uji Glejser. Uji Glejser bekerja dengan cara meregresikan variabel independen terhadap nilai Absolute residual. Dasar pengambilan keputusan uji Glejser yaitu apabila nilai sig $>0,05$ berarti tidak terjadi heteroskedastisitas dalam model regresi, sedangkan apabila nilai sig $<0,05$ berarti terjadi heteroskedastisitas dalam model regresi.

Pengujian hipotesis pada penelitian ini menggunakan analisis kualitatif dan analisis kuantitatif. Dimana analisis kualitatif yaitu dengan memaparkan hasil-hasil penelitian di lapangan secara deskriptif, sedangkan analisis kuantitatif yaitu dengan menggunakan angka-angka statistik melalui metode analisis Regresi Linear Berganda untuk mengetahui pengaruh dari dua atau lebih variabel independen (variabel X) terhadap variabel dependen (variabel Y).

Menurut Sugiyono (2010 : 277), model umum bentuk persamaan analisis statistik parametrik Regresi Linear Berganda (Multiple Linear Regression) yaitu:

Dimana :

$$
Y=a+b_{1} X_{1}+b_{2} X_{2}+\cdots+b_{n} X_{n}
$$

$Y \quad=$ Variabel tak bebas (dependen variabel)

$a \quad=$ Konstanta (intercept)

$X_{1}-X_{n} \quad=$ Variabel bebas (independen variabel)

$b_{1}-b_{n}=$ Koefisien variabel bebas

Dalam penelitian ini, bentuk persamaan di atas menjadi:

Dimana:

$$
Y=a+b_{1} X_{1}+b_{2} X_{2}+b_{3} X_{3}+b_{4} X_{4}
$$

$Y \quad=$ Keputusan pembelian konsumen

$a \quad=$ Konstanta

$X_{1} \quad=$ Produk

$X_{2}=$ Harga 


\section{JMUT}

Vol. 6, No.2, Mei 2020, 130-138

$X_{3} \quad=$ Promosi

$X_{4} \quad=$ Tempat

$b_{1}-b_{n}=$ Parameter yang diukur

Menurut Ghozali (2013 : 98) uji F berfungsi untuk mengetahui pengaruh simultan dari seluruh variabel independen $(\mathrm{X})$ terhadap variabel dependen $(\mathrm{Y})$. Rumusan hipotesis pada penelitian ini yaitu: $\mathrm{H}_{0} \quad$ : Bauran pemasaran berpengaruh tidak signifikan terhadap keputusan pembelian produk Eiger di Universias Tadulako.

$\mathrm{H}_{1} \quad$ : Bauran pemasaran berpengaruh signifikan terhadap keputusan pembelian produk Eiger di Universias Tadulako.

Kriteria pengujian pada penelitian ini ditetapkan berdasarkan nilai signifikansi (Sig), dimana apabila nilai sig $<0,05$ maka $\mathrm{H}_{0}$ ditolak dan $\mathrm{H}_{1}$ diterima. Sedangkan apabila nilai sig > 0,05, maka $\mathrm{H}_{0}$ diterima dan $\mathrm{H}_{1}$ ditolak. Dari tabel selain itu juga diperoleh kofisien determinasi $\left(\mathrm{R}^{2}\right)$ yang berfungsi untuk mengetahui seberapa besar pengaruh yang diberikan oleh variabel independen (X) secara simultan terhadap variabel dependen $(\mathrm{Y})$. Apabila nilai koefisien determinasi $\left(\mathrm{R}^{2}\right)$ berada antara $0-1$ atau mendekati satu, maka model regresi linier berganda nilai sangat kuat.

Uji t berfungsi untuk mengetahui apakah variabel independen secara parsial mempunyai pengaruh yang signifikan terhadap variabel dependen. Dalam Ghozali (2005 : 85) dikemukakan bahwa dasar pengambilan keputusan pada uji $\mathrm{t}$ yaitu melalui bilangan probabilitas signifikansi. Jika nilai signifikansi (Sig.) < 0,05, maka variabel indepanden $(\mathrm{X})$ berpengaruh terhadap variabel dependen $(\mathrm{Y})$ atau hipotesis diterima. Namun Jika nilai signifikansi (Sig.) $>0,05$, maka variabel indepanden (X) tidak berpengaruh terhadap variabel dependen $(\mathrm{Y})$ atau hipotesis ditolak.

\section{HASIL DAN PEMBAHASAN}

Kuisioner yang disebarkan dalam penelitian ini berjumlah 60 kuisioner dengan subyek penelitian adalah konsumen yang menggunakan produk Eiger. Umur responden yang menggunakan produk Eiger dalam penelitian ini adalah berkisar antara 18-23 Tahun, berjenis kelamin laki-laki sebanyak 39 orang dan berjenis kelamin perempuan sebanyak 21 orang. Responden berasal dari sembilan fakultas yaitu Ekonomi, FAPETKAN, FISIP, FKIP, Hukum, Kehutanan, MIPA, Pertanian dan Teknik. Data penelitian menunjukkan bahwa hampir semua mahasiswa di setiap Jurusan di Universitas Tadulako menggunakan produk Eiger. Dalam penelitian ini 23 jurusan di Universitas Tadulako menjadi sasaran penelitian penulis yaitu Jurusan Agribisnis, Agroteknologi, Akuntansi, Arsitektur, bahasa dan seni, Elektro, Fisika, Hukum, Ilmu Administrasi Publik, ilmu Pemerintahan, Ilmu Pendidikan, IPS, Kehutanan, Kimia, Manajemen, Matematika, Mesin, MIPA, Pembangunan, Perikanan, Peternakan, Sipil dan Sosiologi. Seluruh responden yang menggunakan produk Eiger adalah angkatan 2015-2018.

Berdasarkan hasil penelitian, diketahui bahwa 21 orang responden membeli produk Eiger sebanyak lebih dari tiga dengan presentase 35,0\%. Disamping itu tas (bag) adalah produk Eiger paling banyak yang terakhir kali dibeli oleh responden, dengan jumlah responden yang membeli sebanyak 21 orang, presentase sebesar 35,0\%. Dari 60 responden, 41 orang responden membeli produk Eiger dengan kisaran harga $R p .100 .000-R p .500 .000$ dengan presentase $68,3 \%$. 16 orang responden membeli produk Eiger dengan kisaran harga $R p .500 .000-R p .1 .000 .000$ dengan presentase 26,7\%. Sedangkan responden yang membeli produk Eiger dengan kisaran harga $>R p .1 .000 .000$ sebanyak 1 orang dengan presentase $1,7 \%$. Jadi dapat disimpulkan bahwa minat beli responden terhadap produk Eiger sangat tinggi karena responden rela mengeluarkan uang dalam jumlah besar demi mendapatkan produk Eiger.

Uji validitas digunakan untuk mendapatkan informasi mengenai valid tidaknya suatu kuisioner. Dari hasil penelitian didapatkan nilai Corrected item-total correlation semua indikator variabel > 0,30 , sehingga semua indikator variabel pada kuisioner dalam penelitian ini dinyatakan valid atau 
sahih. Selain itu didapatkan nilai Cronbach's Alpha seluruh variabel pada kuisioner bernilai lebih dari 0,60 , sehingga semua indikator variabel pada kuisioner dalam penelitian ini dinyatakan dianggap reliable.

Tabel diatas menunjukkan bahwa nilai signifikansi semua variabel independen lebih besar daripada 0,05. Sehingga menurut dasar pengambilan keputusan uji Glejser, dapat disimpulkan bahwa tidak terjadi gejala heteroskedastisitas dalam model regresi pada penelitian ini.

Tabel 7. Hasil Analisis Regresi Linear Berganda

a. Dependent Variable: Abs_RES

\begin{tabular}{|c|c|c|c|c|c|c|}
\hline \multicolumn{7}{|c|}{ Coefficients $^{a}$} \\
\hline \multirow{2}{*}{\multicolumn{2}{|c|}{ Model }} & \multicolumn{2}{|c|}{$\begin{array}{l}\text { Unstandardized } \\
\text { Coefficients }\end{array}$} & \multirow{2}{*}{$\begin{array}{c}\text { Standardized } \\
\text { Coefficients } \\
\text { Beta }\end{array}$} & \multirow[b]{2}{*}{$\mathrm{T}$} & \multirow[b]{2}{*}{ Sig. } \\
\hline & & $B$ & Std. Error & & & \\
\hline \multirow[t]{5}{*}{1} & (Constant) & .150 & 1.236 & & .121 & .904 \\
\hline & Produk (X1) & .151 & .058 & .131 & 2.603 & .012 \\
\hline & Harga (X2) & .216 & .060 & .254 & 3.573 & .001 \\
\hline & Promosi (X3) & .198 & .054 & .217 & 3.698 & .001 \\
\hline & Tempat (X4) & .600 & .087 & .565 & 6.871 & .000 \\
\hline
\end{tabular}

a. Dependent Variable: Keputusan Pembelian (Y)

Berdasarkan pendapat Sugiyono (2010 : 277), maka persamaan analisis Regresi Linear Berganda dalam penelitian ini adalah sebagai berikut:

$$
\begin{gathered}
Y=a+b_{1} X_{1}+b_{2} X_{2}+b_{3} X_{3}+b_{4} X_{4} \\
Y=0,150+0,151 X_{1}+0,216 X_{2}+0,198 X_{3}+0,600 X_{4} X_{1}
\end{gathered}
$$

Adapun makna dari persamaan regresi di atas yaitu:

1. Nilai konstanta yang didapatkan adalah 0,150 . Nilai konstanta yang positif berarti bahwa variabel independen memiliki pengaruh positif

2. Nilai variabel produk $\left(\mathrm{X}_{1}\right)$ adalah 0,151 . Hal ini berarti bahwa jika kinerja produk $\left(\mathrm{X}_{1}\right)$ mengalami kenaikan satu-satuan maka keputusan pembelian (Y) akan mengalami peningkatan sebesar 0,151 atau $15,1 \%$. Koefisien ini bernilai positif, sehingga kinerja antara produk $\left(\mathrm{X}_{1}\right)$ dan keputusan pembelian (Y) berhubungan positif.

3. Nilai variabel harga $\left(X_{2}\right)$ adalah 0,216 . Hal ini berarti bahwa jika kinerja harga $\left(X_{2}\right)$ mengalami kenaikan satu-satuan maka keputusan pembelian (Y) akan mengalami peningkatan sebesar 0,216 atau $21,6 \%$. Koefisien ini bernilai positif, sehingga kinerja antara harga $\left(\mathrm{X}_{2}\right)$ dan keputusan pembelian (Y) berhubungan positif.

4. Nilai variabel promosi $\left(\mathrm{X}_{3}\right)$ adalah 0,198 . Hal ini berarti bahwa jika kinerja promosi $\left(\mathrm{X}_{3}\right)$ mengalami kenaikan satu-satuan maka keputusan pembelian (Y) akan mengalami peningkatan sebesar 0,198 atau 19,8\%. Koefisien ini bernilai positif, sehingga kinerja antara promosi ( $\left.\mathrm{X}_{3}\right)$ dan keputusan pembelian $(\mathrm{Y})$ berhubungan positif.

5. Nilai variabel tempat $\left(\mathrm{X}_{4}\right)$ adalah 0,600 . Hal ini berarti bahwa jika kinerja tempat $\left(\mathrm{X}_{4}\right)$ mengalami kenaikan satu-satuan maka keputusan pembelian (Y) akan mengalami peningkatan sebesar 0,600 atau $60,0 \%$. Koefisien ini bernilai positif, sehingga kinerja antara tempat $\left(\mathrm{X}_{4}\right)$ dan keputusan pembelian (Y) berhubungan positif. 
Uji $\mathrm{F}$ berfungsi untuk mengetahui apakah seluruh variabel independen $(\mathrm{X})$ secara simultan mempunyai pengaruh signifikan terhadap variabel dependen (Y). Nilai Sig. yang diperoleh sebesar 0,000 berarti nilai Sig. tersebut lebih kecil dari 0,05, Sehingga dapat disimpulkan bahwa hipotesis diterima atau dengan kata lain secara simultan bauran pemasaran berpengaruh signifikan terhadap keputusan pembelian produk Eiger di Universias Tadulako.

Nilai R Square adalah sebesar 0,871. Nilai ini didapatkan melalui pengkuadratan nilai " $R$ " yaitu $0,933 \times 0,933=0,871$. Besarnya nilai koefisien determinasi ( $R$ Square) adalah 0,871 atau sama dengan $87,1 \%$. Artinya bahwa variabel bauran pemasaran (X) secara simultan mempengaruhi keputusan pembelian produk Eiger di Universitas Tadulako (Y) sebesar 87,1\%. Sedangkan sisanya 12,9\% dari 100\% dipengaruhi oleh variabel lain di luar persamaan Regresi Linear Berganda ini atau dipengaruhi oleh variabel lain yang tidak diteliti. Besarnya pengaruh variabel lain disebut juga sebagai error (e). Untuk menghitung nilai error tersebut dapat digunakan rumus $e=1-R^{2}$. Besarnya nilai koefisien determinasi atau $\mathrm{R}$ Square ini umumnya berkisar antara $0-1$. Jika nilai $\mathrm{R}$ Square negitif, maka berarti tidak terdapat pengaruh variabel independen $(\mathrm{X})$ terhadap variabel dependen $(\mathrm{Y})$. Sebaliknya jika nilai R Square positif, berarti terdapat pengaruh variabel independen $(X)$ terhadap variabel dependen $(\mathrm{Y})$. Namun semakin kecil nilai $\mathrm{R}$ square pengaruh variabel independen $(\mathrm{X})$ terhadap variabel dependen (Y) dianggap semakin lemah. Sedangkan semakin besar nilai R square mendekati angka 1 maka pengaruh variabel independen $(\mathrm{X})$ terhadap variabel dependen $(\mathrm{Y})$ akan semakin kuat.

Uji $t$ berfungsi untuk mengetahui apakah variabel independen (X) secara parsial mempunyai pengaruh yang signifikan terhadap variabel dependen $(\mathrm{Y})$. Nilai signifikansi variabel produk $\left(\mathrm{X}_{1}\right)$ sebesar 0,012. Karena nilai Sig. 0,012 $<0,05$, maka dapat disimpulakan bahwa $\mathrm{H}_{1}$ diterima. Artinya variabel produk secara parsial berpengaruh sigifikan terhadap keputusan pembelian produk Eiger di Universias Tadulako. Nilai signifikansi variabel harga $\left(\mathrm{X}_{2}\right)$ sebesar 0,001. Karena nilai Sig. 0,001< 0,05, maka dapat disimpulakan bahwa $\mathrm{H}_{2}$ diterima. Artinya variabel harga secara parsial berpengaruh sigifikan terhadap keputusan pembelian produk Eiger di Universias Tadulako. Nilai signifikansi variabel promosi $\left(\mathrm{X}_{3}\right)$ sebesar 0,001 . Karena nilai Sig. 0,001<0,05, maka dapat disimpulakan bahwa $\mathrm{H}_{3}$ diterima. Artinya variabel promosi secara parsial berpengaruh sigifikan terhadap keputusan pembelian produk Eiger di Universias Tadulako. Sedangkan nilai signifikansi variabel tempat $\left(\mathrm{X}_{4}\right)$ sebesar 0,000. Karena nilai Sig. 0,000 $<0,05$, maka dapat disimpulkan bahwa $\mathrm{H}_{4}$ diterima. Artinya variabel tempat secara parsial berpengaruh sigifikan terhadap keputusan pembelian produk Eiger di Universias Tadulako.

\section{KESIMPULAN DAN SARAN [Times New Roman 12 Bold, Spasi 1,15]}

\section{Kesimpulan}

Berdasarkan hasil penelitian yang telah dijabarkan, maka diperoleh kesimpulan mengenai pengaruh bauran pemasaran terhadap keputusan konsumen menggunakan produk Eiger di Universitas Tadulako sebagai berikut:

1. Bauran pemasaran yang terdiri dari produk, harga, promosi dan tempat secara simultan atau besama-sama berpengaruh signifikan terhadap keputusan konsumen menggunakan produk Eiger di Universitas Tadulako.

2. Variabel produk secara parsial berpengaruh signifikan terhadap keputusan konsumen menggunakan produk Eiger di Universitas Tadulako.

3. Variabel harga secara parsial berpengaruh signifikan terhadap keputusan konsumen menggunakan produk Eiger di Universitas Tadulako. 
4. Variabel promosi secara parsial berpengaruh signifikan terhadap keputusan konsumen menggunakan produk Eiger di Universitas Tadulako.

5. Variabel tempat secara parsial berpengaruh signifikan terhadap keputusan konsumen menggunakan produk Eiger di Universitas Tadulako.

\section{Saran}

Berdasarkan pengamatan penulis mengenai pengaruh bauran pemasaran terhadap keputusan konsumen menggunakan produk Eiger di Universitas Tadulako, maka penulis menyampaikan beberapa saran untuk menjadi acuan dalam mewujudkan suatu konsep bauran pemasaran yang lebih baik. Bagi perusahaan Eiger diharapkan untuk lebih meningkatkan kegiatan promosi agar konsumen semakin mengenal dan tertarik untuk membeli setiap produk Eiger yang ditawarkan dalam pasar. Hal ini juga berguna untuk menambah jaringan konsumen agar semakin meluas. Misalnya promosi dapat lebih intens lagi disajikan melaui media sosial atau melaui iklan pada televisi. Selain itu, dengan melihat jenis kebutuhan konsumen yang semakin beragam, maka diharapkan agar perusahaan Eiger lebih tanggap dalam melihat potensi kebutuhan konsumen misalnya dengan lebih cepat dalam menyediakan produk baru di setiap toko Eiger yang tersebar serta harus lebih cepat dalam menyetok persediaan jenis produk yang sudah habis di toko.

Selanjutnya, untuk peneliti lain yang tertarik dengan penelitian ini dapat mengembangkannya dengan meneliti faktor lain yang dapat mempengaruhi keputusan pembelian. Peneliti selanjutnya dapat juga menggunakan metode lain dalam meneliti keputusan pembelian, misalnya melalui wawancara terhadap responden, sehingga informasi yang diperoleh dapat lebih bervariasi daripada angket yang jawabannya telah tersedia.

\section{REFERENSI}

Azwar, Saifudin. 2003. Validitas dan Reliabilitas, Edisi kesatu, Pustaka Pelajar, Yogyakarta.

Charles lamb, W. dkk 2001. Pemasaran. Edisi Pertama, Salemba Empat : Jakarta.

Febrian, A. 2013. Pengaruh Citra Merek Terhadap Keputusan Pembelian Tas Eiger di Bandar Lampung. Bandar Lampung : Fakultas Ekonomi dan Bisnis, Universitas Lampung.

Ghozali, I. 2005. Aplikasi Analisis Multivariate Dengan Program IBM SPSS 19. Semarang : Universitas Diponegoro.

Ghozali, I. 2006. Aplikasi Analisis Multivariate Dengan Program SPSS (Edisi ke 4). Semarang : Badan Penerbit Universitas Diponegoro.

Ghozali, I. 2013. Aplikasi Analisis Multivariate Dengan Program IBM SPSS 21 Update PLS Regresi. Semarang : Badan Penerbit Universitas diponegoro.

Infobdg.com. 2018. Mengintip Proses Produksi Tas Eiger. https://www.infobdg.com/v2/mengintipproses-produksi-tas-eiger/amp/. (diakses tanggal 9 Juni 2019).

Kotler, Philip. 2005. Manajemen Pemasaran. Jilid 1 dan 2. Jakarta: PT. Prenhallindo.

Kotler, Philip \& Amstrong, Gray. 2008. Prinsip-prinsip Pemasaran, Jilid 1 Edisi ke 12 Erlangga, Jakarta.

Kotler, Philip \& Amstrong, Gray. 2009. Prinsip-prinsip Pemasaran, Jilid 2 Edisi ke 12 Erlangga, Jakarta.

Kotler, Philip \& Keller, Kevin Lane. 2009. Manajemen Pemasaran, Jilid 1 Edisi ke 13 Erlangga, Jakarta. 
Sugiyono. 2010. Motode Penelitian Bisnis: Alfabeta, Bandung.

Sujarweni, V. Wiratna. 2014. Metode Penelitian: Lengkap, Praktis, dan Mudah Dipahami. Yogyakarta: Pustaka Baru Press.

Tjiptono, F., G. Chandra dan D. Adriana. 2008. Pemasaran Strategi. Andi Offset. Yogyakarta.

Umar, Husein. 2003. Metode Penelitian Skripsi dan Tesis Bisnis. Edisi Baru. Jakarta: PT. Raja Grafindo Persada.

Uma Sekaran. 2006. Metode Penelitian Bisnis. Jakarta: Salemba Empat. 